\title{
EFFect OF COWPEA INTERCROPPING ON WEED CONTROL AND CORN YIELD $^{1}$
}

\author{
Efeito da Consorciação do Feijão-Caupi no Controle de Plantas Daninhas e no Rendimento \\ do Milho
}

\begin{abstract}
SILVA, P.S.L. ${ }^{2}$, OLIVEIRA, O.F. ${ }^{3}$, SILVA, P.I.B. ${ }^{4}$, SILVA, K.M.B. ${ }^{5}$ and BRAGA, J.D. ${ }^{6}$
ABSTRACT - Herbicides have simplified weed control, but the use of herbicides, besides being costly, resulted in the selection of herbicide-resistant weed biotypes and has become an environmental contamination factor. Herbicide use reduction is one of the goals of modern agriculture, with several alternatives being investigated, including intercropping. The objective of this study was to evaluate the effects of cowpea and corn cultivar intercropping on weed control and corn green-ear (immature ears with 80\% humidity grains) and grain yield. A completely randomized block design with split-plots and four replications was used. AG 1051, AG 2060 and PL 6880 corn cultivars (assigned to plots) were submitted to the four treatments: no weeding, two hoe-weeding (22 and 41 days after planting), and intercropping with cowpea (BR 14 and IPA 206 cultivars, with indeterminate growth). The cowpea was planted (with corn planting) between the corn rows, in pits $1.0 \mathrm{~m}$ apart, with two plants per pit. The corn cultivars did not differ from each other as to weed density (WD), fresh aboveground weed biomass (WB), green-ear yield and grain yields. Higher WD and WB mean values were found in no weeding subplots; lower mean values in two hoe-weeding subplots; and intermediate mean values in intercropped subplots, indicating that cowpea plants had, to a certain extent, control over weeds. The no-weeded plots and the intercropped plots had lower green-ear and grain yields. Although the cowpea cultivars had a certain control over weeds (mean reductions of 22.5 and $18.3 \%$, in terms of green matter density and weight of the above-ground part of weeds, respectively), they also competed against the corn plants, leading to yield reduction (mean reductions of 17.0 and $32 \%$ in green ear and grain yield, respectively). The cowpea cultivars did not produce grain, certainly due to the strong competition exerted by the corn and weeds on cowpea plants.
\end{abstract}

Keywords: Zea mays, Vigna unguiculata, cultivars, green-ear yield, grain yield.

RESUMO - Os herbicidas têm simplificado o controle de plantas daninhas, mas, além de caros, têm causado o surgimento de biótipos de plantas daninhas a eles resistentes e se tornado fator de contaminação ambiental. A redução do uso de herbicidas é um dos objetivos da agricultura moderna, e várias alternativas estão sendo investigadas, incluindo a consorciação. O objetivo deste trabalho foi avaliar os efeitos da consorciação de cultivares de feijão-caupi com cultivares de milho sobre o controle de plantas daninhas e os rendimentos de espigas verdes (espigas imaturas com grãos com teor de umidade de 80\%) e de grãos do milho. Utilizou-se o delineamento de blocos casualizados com parcelas subdivididas e quatro repetições. Os cultivares de milho AG 1051, AG 2060 e PL 6880 (atribuidos às parcelas) foram submetidos a quatro tratamentos: sem capina, duas capinas (aos 22 e 41 dias após a semeadura) e milho consorciado com feijão-caupi (cultivares BR 14 e IPA 206, com crescimento indeterminado). O feijão-caupi foi semeado (por ocasião da semeadura do milho) entre as fileiras do milho, em covas distanciadas de 1,0 m, com duas plantas/cova. Os

1 Recebido para publicação em 13.6.2008 e na forma revisada em 15.5.2009.

2 Agronomist, Ph.D., Universidade Federal Rural do Semi-Árido - UFERSA, Caixa Postal 137, 59625-900 Mossoró-RN, CNPq fellow, <paulosergio@ufersa.edu.br>; ${ }^{3}$ Agronomist, M.Sc., UFERSA(retired professor), <odaci@uol.com.br>; ${ }^{4}$ Agronomist, Doctorate program student, Universidade Federal de Viçosa - UFV , <pauloigor@alunos.ufersa.edu.br>; ${ }^{5}$ Agronomist, Ph.D., Professor, Biological Sciences Dept., Universidade do Estado do Rio Grande do Norte - UERN, 59610-090 Mossoró-RN, <kmbsbarbosa@yahoo.com.br>; ${ }^{6}$ Agronomy student - UFERSA, CNPq fellow, <eng.jefferson@uol.com.br>

Planta Daninha, Viçosa-MG, v. 27, n. 3, p. 491-497, 2009 
cultivares de milho não diferiram entre si quanto à densidade e biomassa fresca da parte aérea de plantas daninhas, bem como quanto aos rendimentos de espigas verdes e grãos. As médias mais elevadas da densidade e da biomassa de plantas daninhas foram encontradas em subparcelas sem controle de plantas daninhas (sem capinas); as menores médias, em subparcelas com controle de plantas daninhas (duas capinas); e as médias intermediárias, nas subparcelas consorciadas, indicando que os cultivares de feijão-caupi exerceram, em certa extensão, controle das plantas daninhas. As subparcelas sem controle de plantas daninhas e as subparcelas consorciadas apresentaram os menores rendimentos de espigas verdes e grãos. Embora os cultivares de feijãocaupi tenham tido certo controle sobre as plantas daninhas (reduções médias de 22, 5 e de 18,3\%, em termos de densidade e peso da matéria fresca da parte aérea de plantas daninhas, respectivamente), elas também competiram com o milho, causando redução nos rendimentos (reduções médias de 17,0 e 32\%, nos rendimentos de espigas verdes e de grãos, respectivamente). Os cultivares de feijão-caupi não produziram grãos devido, certamente, à forte competição exercida pelo milho e plantas daninhas sobre as plantas do feijão-caupi.

Palavras-chave: Zea mays, Vigna unguiculata, cultivares, rendimento de espigas verdes, rendimento de grãos.

\section{INTRODUCTION}

Corn is a major crop in Brazil, cultivated throughout the country for the production of fresh green ears and dry grains. Fresh green ears are immature ears with kernels at the stage of $80 \%$ humidity and are consumed by the Brazilian people in different ways (roasted, cooked and/or ingredient in local recipes). The dry grains are processed for human consumption or animal feeding. Weeds usually reduce green ear and dry grain yields up to $60 \%$ and $80 \%$, respectively (Silva et al., 2004a, b).

Corn yield losses due to weeds depend on the corn cultivar grown, species and number of weeds per area, competition period, and corn development stage. Besides reducing yield, weeds can reduce grain quality, cause irregular maturation and harvesting difficulties, as well as act as hosts for pests and pathogens (Silva et al., 2004a). In addition, weeds can deplete nutrients from soils (Sreenivas \& Satyanarayana, 1996). Herbicides have simplified weed control and are extensively used, even replacing cultural weed control methods in several regions. However, the extensive use of herbicides, besides being costly, has caused herbicideresistant weed biotypes to evolve, turning this practice into an environmental contamination factor. Reduction of herbicide use is one of the major goals of modern agriculture (Ngouajio et al., 1999) and several alternatives are currently being investigated with this objective
(Carruthers et al., 1998). The weed-control cultural practices studied in the past have again become interesting (Nalewaja, 1999) and are being currently studied, including intercropping (Gomes et al., 2007).

Reduced weed incidence in corn by intercropping depends on several factors, including planting season and intercropping species used (Skóra Neto, 1993), fertilizer doses (Olasantan et al., 1994), corn cultivar and year of evaluation (Kuchinda et al., 2003), among other factors. Efficacy of cover crops depends most on soil coverage (> 50\%), with light interception being the most important effect (Steinmaus et al., 2008). Cover crop efficiency is achieved by a rapid occupation of the open space between the main crop rows, preventing weed seed germination and reducing weed seedling growth and development. Weed seed germination may be inhibited by either complete light interception due to cover crop or allelochemical secretion. After weed seedling establishment, resource competition becomes the cover crop's main weed suppressing mechanism of cover crop (Hollander et al., 2007).

Cowpea (Vigna unguiculata) is a widely adapted, stress-tolerant grain legume, vegetable, and fodder crop grown on about 7 million ha in warm to hot regions in Africa, Asia and the Americas (Ehlers \& Hall, 1997). Cowpea can produce abundant biomass and fix substantial amounts of atmospheric nitrogen (Creamer \& Baldwin, 2000). In 
addition, cowpea rarely requires fertilizers and can suppress weeds (Hutchinson \& McGiffen, 2000). Cowpea has been identified as an ideal cover crop for many areas (Wang et al., 2006).

Differences have been observed among corn genotypes (Begna et al., 2001; Gomes et al., 2007), as well as among cowpea cultivars (Wang et al., 2004), as to their tolerance or competitive capacity over weeds. Therefore, identification of corn-cowpea cultivars with high tolerance or competitive capacity over weeds is highly desirable. The objective of this study was to evaluate the effects of cowpea cultivars intercropped with corn cultivars on weed control and corn green-ear and grain yields.

\section{MATERIAL AND METHODS}

The experiment was carried out at "Rafael Fernandes" Experimental Farm $\left(5^{\circ} 11^{\prime} \mathrm{S}\right.$ latitude, $37^{\circ} 20^{\prime} \mathrm{W}$ longitude, and $18 \mathrm{~m}$ altitude), under sprinkling irrigation. The experimental soil was classified as Red-yellow Euthrophic Argisol, according to the Brazilian Soil Classification System (Embrapa, 1999), and as Ferric Lixisol, according to the Soil Map of the World (FAO/UNESCO, 2006). Soil chemical analysis indicated: $\mathrm{pH}=6.8 ; \mathrm{Ca}=$ $1.80 \mathrm{cmol}_{\mathrm{c}} \mathrm{dm}^{-3} ; \mathrm{Mg}=0.40 \mathrm{cmol}_{\mathrm{c}} \mathrm{dm}^{-3} ; \mathrm{K}=$ $0.10 \mathrm{cmol}_{\mathrm{c}} \mathrm{dm}^{-3} ; \mathrm{Na}=0.01 \mathrm{cmol}_{\mathrm{c}} \mathrm{dm}^{-3} ; \mathrm{Al}=$ $0.00 \mathrm{cmol} \mathrm{dm}^{-3} ; \mathrm{P}=25 \mathrm{mg} \mathrm{dm}^{-3} ;$ Org. Mat. $=19.0 \mathrm{~g} \mathrm{~kg}^{-1}$. Soil physical analysis indicated: 94.7 and $1.0 \%$ silt, $4.3 \%$ clay, and $1.76 \mathrm{~g} \mathrm{~cm}^{3}$ density (Mota, 2004).

Soil tillage was accomplished with a tractor, by means of two cross harrowings, and fertilized with $30 \mathrm{~kg} \mathrm{~N}$ (urea), $60 \mathrm{~kg} \mathrm{P}_{2} \mathrm{O}_{5}$ (simple super phosphate) and $30 \mathrm{~kg} \mathrm{~K}_{2} \mathrm{O}$ (potassium chloride), per hectare. The fertilizers were applied in furrows located alongside and below the sowing furrows. Corn sowing was conducted on 08.19.2004, and four seeds were used per pit. Rows were $1.0 \mathrm{~m}$ apart, with pits on the same row were spaced at $0.4 \mathrm{~m}$. Thinning was performed 17 days after planting, leaving the two most vigorous plants in each pit. Thus, the programmed population stand in the experiment was 50 thousand plants $\mathrm{ha}^{-1}$. After thinning. Deltamethrin (250 $\mathrm{ml} \mathrm{ha}^{-1}$ ) was sprayed 12 days after planting to control the fall armyworm (Spodoptera frugiperda Smith), the main corn pest in the region. The sprays were performed using a back-pack sprayer. Urea (30 $\mathrm{kg} \mathrm{ha}^{-1}$ ) sidedressings were performed at 22 and 41 days after planting.

A completely randomized block design in split-plots was used with five replications. Each subplot consisted of four 6.0-m-long rows (gross plot). A usable area was considered that occupied by $5.2 \mathrm{~m}$ in the two central rows (net plot). The corn cultivars AG 1051, AG 2060 and PL 6880 (assigned to plots) were submitted to the following treatments: non-weeding, hoeweeding (22 and 41 days after planting), and intercropping with cowpea (BR 14 and IPA 206 cultivars, with indeterminate growth). Cowpea was planted (with corn planting) between the corn rows, in spaced $1.0 \mathrm{~m}$ spaced pits, two plants per pit. Weeding was performed with a hoe and the same worker was assigned to it in each block. The other experimental operations were performed by hand.

One of the rows in the net plot was selected to evaluate green-ear yield, while the other rows were used to assess grain yield and its components. Green corn was harvested at 70, 73 and 75 days after sowing. Green ear yield was evaluated based on number and weight of both total ears and marketable corn ears, either unhusked or husked. Ears with a length equal to or above $22 \mathrm{~cm}$ and without signs of pest attack were considered as marketable unhusked corn ears. Healthy $18 \mathrm{~cm}$ or longer husked corn ears with grain set suitable for commercialization were classified as marketable. Corn plant and ear heights (from all plants in the net plot) were evaluated after the last green corn harvest. The distance from ground level to the insertion point of the highest leaf blade was considered as plant height. The distance from the ground level to the insertion point of the highest ear was considered as ear height. Grain yield was estimated from mature corn ears harvested in the other row of the net plot. Number of ears $\mathrm{ha}^{-1}$ was estimated based on number of mature ears Number of kernels per ear was estimated on a 10-ear sample basis. The estimation of 100-kernel weight was based on the weight and number of kernels in that sample's ears. Grain yield was corrected for $15.5 \%$ moisture content (wet basis). 
The composition, distribution, and aboveground biomass (fresh weight) of weeds found in the experiment were evaluated after harvesting the mature ears. The weeds were cut even with the ground in two randomly sorted areas delimited by a $0.5 \times 0.5 \mathrm{~m}$ wooden frame in the net plot subplot. Weed species relative frequency (Shrestha et al., 2002) was calculated based on the information obtained from each subplot (in both $0.5 \times 0.5 \mathrm{~m}$ areas sampled from each subplot, as previously mentioned) and was defined as the ratio between number of plots where each species occurred and total number of plots (60) in the experiment.

The data was submitted to analyses of variance using the software developed at the Federal University of Viçosa (UFV), MG, Brazil (Ribeiro Junior, 2001) and the means were compared by the Tukey test $(\mathrm{P}<0.05)$. The data were submitted to the variance homogeneity test before the statistical analyses ere performed (Bartlett, 1937). Before the analysis of variance, the corresponding data were transformed into square root, as weed count tended to follow the Poisson distribution (Bartlett, 1947).

\section{RESULTS AND DISCUSSION}

Twenty-one weed species occurred in the experiment area, with the majority of them (19\%) belonging to the Poaceae family (Table 1).The species were grouped into approximately equal proportions according to habit $(52 \%$ perennial and the remainder annual) (Table 1). The most frequent weed species were Borreria verticillata, Hyptis suaveolens, Adenocalymma sp., Borreria scabiosoides, Panicum repens, Mitracarpus selloanus, Ipomoea bahiensis and Commelina sp. Other species, such as Cucumis anguria, Dactyloctenium aegyptium, Evolvulus ovatus, Jacquemontia sp., Passiflora foetida and

Table 1 - Family, habit, and relative frequency (ratio between the number of experimental units in which a species occurs and the total number of experimental units) for the main weed species identified in the experimental area, considering all experimental units and weed control methods

\begin{tabular}{|c|c|c|c|c|c|c|c|}
\hline \multirow[b]{3}{*}{ Weed species } & \multirow[b]{3}{*}{ Family } & \multirow[b]{3}{*}{ Habit } & \multicolumn{5}{|c|}{ Relative frequency $(\%)$} \\
\hline & & & \multirow[b]{2}{*}{$\begin{array}{c}\text { In all } \\
\text { experimental } \\
\text { units }\end{array}$} & \multicolumn{4}{|c|}{ According to weed control method } \\
\hline & & & & $\begin{array}{c}\text { Hoe- } \\
\text { weeding }\end{array}$ & $\begin{array}{l}\text { Intercropping } \\
\text { with cowpea } \\
\text { (BR } 14 \mathrm{cv} \text { ) }\end{array}$ & $\begin{array}{l}\text { Intercropping } \\
\text { with cowpea } \\
\text { (IPA } 206 \mathrm{cv} \text {.) }\end{array}$ & $\begin{array}{c}\text { No. } \\
\text { weeding }\end{array}$ \\
\hline Adenocalymma sp. & Bignoniaceae & Perennial & 38.3 & 60.0 & 33.3 & 33.3 & 26.7 \\
\hline Alternanthera ficoideae (L.) R. Br. & Amaranthaceae & Perennial & 6.7 & 6.7 & 0.0 & 13.3 & 6.7 \\
\hline Bauhinia heterandra Benth. & Leguminosae & Perennial & 6.7 & 13.3 & 6.7 & 0.0 & 0.0 \\
\hline Borreria scabiosoides Cham. et Schlecht. & Rubiaceae & Perennial & 26.7 & 33.3 & 40.0 & 13.3 & 20.0 \\
\hline Borreria verticillata G.F.W. Meyer & Rubiaceae & Perennial & 98.3 & 93.3 & 100.0 & 100.0 & 100.0 \\
\hline Commelina sp. & Commelinaceae & Perennial & 11.7 & 13.3 & 13.3 & 13.3 & 6.7 \\
\hline Cucumis anguria $\mathrm{L}$. & Cucurbitaceae & Annual & 1.7 & 6.7 & 0.0 & 0.0 & 0.0 \\
\hline Dactyloctenium aegyptium(L.) Beauv. & Poaceae & Annual & 1.7 & 0.0 & 0.0 & 0.0 & 6.7 \\
\hline Digitaria sanguinalis (L.) Scop. & Poaceae & Annual & 3.3 & 6.7 & 6.7 & 0.0 & 0.0 \\
\hline Eragrostis ciliaris (L.) R. Br. & Poaceae & Annual & 3.3 & 0.0 & 0.0 & 13.3 & 0.0 \\
\hline Euphorbia hirta $\mathrm{L}$. & Euphorbiaceae & Annual & 3.3 & 6.7 & 0.0 & 0.0 & 0.0 \\
\hline Euphorbia hyssopifolia L. & Euphorbiaceae & Annual & 3.3 & 6.7 & 6.7 & 0.0 & 6.7 \\
\hline Evolvulus ovatus Fernald & Convolvulaceae & Annual & 1.7 & 0.0 & 0.0 & 0.0 & 6.7 \\
\hline Herissantia crispa $($ L.) Briz & Malvaceae & Perennial & 6.7 & 6.7 & 6.7 & 0.0 & 13.3 \\
\hline Hyptis suaveolens $\mathrm{L}$. & Labiatae & Annual & 48.3 & 33.3 & 26.7 & 80.0 & 53.3 \\
\hline Ipomoea bahiensis Willd. ex Romer et Schultes & Convolvulaceae & Perennial & 13.3 & 0.0 & 20.0 & 20.0 & 13.3 \\
\hline Jacquemontia sp. & Convolvulaceae & Annual & 1.7 & 0.0 & 6.7 & 0.0 & 0.0 \\
\hline Mitracarpus selloanus Cham. et Schlecht. & Rubiaceae & Annual & 15.0 & 6.7 & 20.0 & 13.3 & 20.0 \\
\hline Panicum repens $\mathrm{L}$. & Poaceae & Perennial & 25.0 & 26.7 & 26.7 & 20.0 & 26.7 \\
\hline Passiflora foetida $\mathrm{L}$. & Passifloraceae & Perennial & 1.7 & 0.0 & 0.0 & 0.0 & 6.7 \\
\hline Waltheria indica $\mathrm{L}$. & Sterculiaceae & Perennial & 1.7 & 0.0 & 0.0 & 0.0 & 6.7 \\
\hline
\end{tabular}


Waltheria indica were present in $2 \%$ of the experimental units. The weed population in a given area depends on several factors, including soil seed bank, soil, climate, crop, and agronomic practices. Although comprising different species, few populations are predominant, corresponding to 70 to $90 \%$ of the species total (Buhler, 1999). Reduced relative frequency of the weed species intercropped with cowpea cultivars, compared to the non-hoed treatment, varied depending on the weed species considered. Intercropping with cowpea cultivars reduced the frequency of the species Dactyloctenium aegyptium, Evolvulus ovatus, Herissantia crispa, Passiflora foetida and Waltheria indica. Intercropping with cowpea cultivar BR 14 reduced the frequency of the species Alternanthera ficoideae and Hyptis suaveolens, while intercropping with cowpea cultivar IPA 206 reduced the frequency of the species Borreria scabiosoides, Euphorbia hyssopifolia, and Mitracarpus selloanus.

Since the effects of corn cultivar $\times$ weed control interaction were not significant for the traits evaluated, only the main effect means of both treatment groups are presented here.

Corn cultivars were not significantly different regarding weed density, fresh biomass (dry biomass could not be determined) (Table 2), plant height, ear height, green-ear yield components (Table 3 ), grain yields and yield components (Table 4).

Higher weed density and higher aboveground fresh biomass values were found for weeds in non hoed plots, as expected. Lower values for those traits were found in the hoeweeded plots. The intercropped plots had intermediate values, suggesting that cowpea plants, to a certain extent, were effective as weed controllers, reducing weed intensity in $20-23 \%$, compared to a more effective reduction $(53 \%)$ reported on hoe-weeding (Table 2).

Taller corn plants (Table 3) were found in hoe-weeded plots. Neither weeding nor nonweeding affected ear height $(91.9 \mathrm{~cm}$ on average, $\mathrm{CVa}=$ coefficient of variation for plots $=27.8 \%, \mathrm{CVb}=$ coefficient of variation for subplots $=6.4 \%$ ), corroborating other authors' results (Gomes et al., 2007). The proportion of green ears in the first harvest was higher in hoe-weeded subplots than in either non-hoed subplots or intercropped subplots, indicating that these two treatments delayed green-ear harvest point. As for green-ear yield (Table 3) and grain yields (Table 4), the non-hoed and intercropped subplots did not differ from each other and were both inferior to the hoe-weeded subplots, except for the total number of ears and number of marketable ears (Table 3). Similar results were obtained by Gomes et al. (2007).

Therefore, despite the cowpea cultivars' relative control over weeds, this control was not sufficiently effective to prevent corn greenear and grain yield losses, likely because cowpea also competed with corn plants causing yield reduction. This competition was evidenced by the lower number of mature ears in the 'IPA 206'- intercropped plot (Table 4) and by the lower number of grains per ear in both intercropping treatments (Table 4). Thus, lower corn yields were observed in non-hoed subplots and intercropped subplots due to the

Table 2 - Weed component means ( \pm standard deviation) after mature-ear harvesting in plots of corn cultivars submitted to weed control methods ${ }^{1 /}$

\begin{tabular}{|c|c|c|c|c|}
\hline \multirow{2}{*}{ Method of weed control } & \multicolumn{2}{|c|}{ Weed density } & \multicolumn{2}{|c|}{ Weed above-ground fresh biomass } \\
\hline & (number of plants $\mathrm{m}^{-2}$ ) & $(\%)$ & $\left(\mathrm{g} \mathrm{m}^{-2}\right)$ & $(\%)$ \\
\hline Hoe-weeding & $26.7( \pm 7.4) \mathrm{c}$ & 46.2 & $1,052.0( \pm 361.4) \mathrm{c}$ & 67.5 \\
\hline Intercropping with cowpea (BR $14 \mathrm{cv}$.) & $46.3( \pm 8.3) b$ & 80.1 & $1,350.2( \pm 188.0) \mathrm{ab}$ & 86.6 \\
\hline Intercropping with cowpea (IPA $206 \mathrm{cv}$.) & $44.5( \pm 8.7) b$ & 77.0 & $1,198.3( \pm 301.9) b c$ & 76.9 \\
\hline No weeding & $57.8( \pm 9.7) \mathrm{a}$ & 100.0 & $1,558.7( \pm 283.2) \mathrm{a}$ & 100.0 \\
\hline Means of corn cultivars & 43.8 & - & 1289.8 & - \\
\hline Coefficient of variation for plots, $\%$ & 19.4 & - & 19.2 & - \\
\hline Coefficient of variation for subplots, $\%$ & 8.4 & - & 21.0 & - \\
\hline
\end{tabular}

1/ Means followed by the same letter in the columns do not differ from each other by the Tukey's test $(\mathrm{P}<0.05)$. 
Table 3 - Means ( \pm standard deviation) for corn plant height, proportion of green ears in the first harvest and green-ear yield values of three corn cultivars submitted to weed control methods ${ }^{1 /}$

\begin{tabular}{|c|c|c|c|c|c|c|c|c|}
\hline \multirow{2}{*}{$\begin{array}{l}\text { Method of weed } \\
\text { control }\end{array}$} & \multirow{2}{*}{$\begin{array}{l}\text { Plant height } \\
\quad(\mathrm{cm})\end{array}$} & \multirow{2}{*}{$\begin{array}{c}\begin{array}{c}\text { Proportion of } \\
\text { green ears at } \\
\text { first harvest } \\
(\%)^{2 !}\end{array} \\
\end{array}$} & \multicolumn{2}{|c|}{ Total unhusked green ears $\mathrm{ha}^{-1}$} & \multicolumn{2}{|c|}{$\begin{array}{l}\text { Marketable unhusked } \\
\text { green ears ha }\end{array}$} & \multicolumn{2}{|c|}{ Marketable husked green ears ha ${ }^{-1}$} \\
\hline & & & Number & Yield (kg) & Number & Yield $(\mathrm{kg})$ & Number & Yield $(\mathrm{kg})$ \\
\hline Hoe-weeding & $184( \pm 16.2)$ a & $62.9( \pm 26.3) \mathrm{a}$ & $49167( \pm 3837)$ a & $14108( \pm 1607)$ a & $48269( \pm 4508)$ a & $13857( \pm 1835)$ a & $44840( \pm 7,129)$ a & $8474( \pm 1439)$ \\
\hline $\begin{array}{l}\text { Intercropping with } \\
\text { cowpea (BR } 14 \\
\text { cultivar) }\end{array}$ & $170( \pm 7.8) b$ & $51.6( \pm 18.6) \mathrm{b}$ & $48974( \pm 1198)$ a & $11447( \pm 959) \mathrm{b}$ & $45128( \pm 1370)$ a & $11038( \pm 1288) b$ & $37051( \pm 4348) b$ & $6305( \pm 1008) \mathrm{b}$ \\
\hline $\begin{array}{l}\text { Intercropping with } \\
\text { cowpea (IPA } 206 \\
\text { cultivar) }\end{array}$ & $176( \pm 16.7) \mathrm{ab}$ & $46.0( \pm 18.3) \mathrm{b}$ & $48846( \pm 1905)$ a & $10389( \pm 1512) b$ & $45585( \pm 5133)$ a & $10205( \pm 1811) b$ & $34935( \pm 8429) \mathrm{b}$ & $5701( \pm 1447) b$ \\
\hline No weeding & $173( \pm 16.4) b$ & $52.8( \pm 25.9) \mathrm{b}$ & $47180( \pm 2275) \mathrm{a}$ & $11545( \pm 2366) b$ & $44344( \pm 4976)$ a & $11199( \pm 2337) b$ & $36923( \pm 11007) b$ & $6310( \pm 1853) \mathrm{b}$ \\
\hline $\begin{array}{l}\text { Means of corn } \\
\text { cultivars }\end{array}$ & 175.8 & 53.3 & 48541 & 11872 & 45832 & 11575 & 38437 & 6698 \\
\hline $\begin{array}{l}\text { Coefficient of } \\
\text { variation for plots, \% }\end{array}$ & 14.1 & 32.4 & 3.9 & 18.2 & 9.3 & 18.0 & 27.1 & 28.0 \\
\hline $\begin{array}{l}\text { Coefficient of ariation } \\
\text { for subplots, } \%\end{array}$ & 5.9 & 19.0 & 5.8 & 13.0 & 10.1 & 15.7 & 18.7 & 19.6 \\
\hline
\end{tabular}

${ }^{1 /}$ Means followed by the same letter in the column do not differ by the Tukey's test $(\mathrm{P}<0.05)$. ${ }^{2} / \mathrm{In}$ relation to the total number of green ears harvested in the first of three harvests.

Table 4 - Means ( \pm standard deviation) for corn grain yield values and yield components of three corn cultivars submitted to weed control methods ${ }^{1 /}$

\begin{tabular}{|l|c|c|c|c|}
\hline \multicolumn{1}{|c|}{ Weed control methods } & $\begin{array}{c}\text { No. } \\
\text { of mature ears ha }\end{array}$ & $\begin{array}{c}\text { No. } \\
\text { of kernels ear }^{-1}\end{array}$ & $\begin{array}{c}\text { 100-kernel weight } \\
(\mathrm{g})\end{array}$ & $\begin{array}{c}\text { Grain yield } \\
\left(\mathrm{kg} \mathrm{ha}^{-1}\right)\end{array}$ \\
\hline Hoe-weeding & $47436( \pm 1888) \mathrm{a}$ & $492.7( \pm 75.2) \mathrm{a}$ & $31.7( \pm 3.6) \mathrm{a}$ & $9647( \pm 1487) \mathrm{a}$ \\
\hline Intercropped with cowpea (BR 14 cultivar) & $46539( \pm 3461) \mathrm{ab}$ & $424.6( \pm 40.9) \mathrm{b}$ & $27.0( \pm 2.2) \mathrm{b}$ & $6701( \pm 1216) \mathrm{b}$ \\
\hline Intercropped with cowpea (IPA 206 cultivar) & $43205( \pm 3720) \mathrm{b}$ & $427.1( \pm 48.7) \mathrm{b}$ & $27.3( \pm 2.1) \mathrm{b}$ & $6423( \pm 1118) \mathrm{b}$ \\
\hline No weeding & $47115( \pm 4647) \mathrm{a}$ & $441.7( \pm 103.3) \mathrm{ab}$ & $27.1( \pm 2.8) \mathrm{b}$ & $6636( \pm 1995) \mathrm{b}$ \\
\hline Means of corn cultivars & 46074 & 446.5 & 28.3 & 7352 \\
\hline Coefficient of variation for plots, $\%$ & 8.4 & 20.2 & 10.5 & 27.1 \\
\hline $\begin{array}{l}\text { Coefficient of variation } \\
\text { for subplots, } \%\end{array}$ & 7.5 & 14.7 & 8.2 & 18.1 \\
\hline
\end{tabular}

${ }^{1 /}$ Means followed by the same letter in the column do not differ by the Tukey's test $(\mathrm{P}<0.05)$.

competition between either corn and weed plants or weed plus cowpea plants for water, light and nutrients. Besides, it is important to highlight that weeds have been reported to affect corn plants by reducing their root system (Thomas \& Alisson, 1975) and leaf area (Gomes et al., 2007). It is important to mention that the cowpea cultivars did not produce grain, likely due to the strong corn and weed competition against cowpea plants.

It can be concluded that twenty one weed species occurred at different frequencies in the experimental area. The corn cultivars did not differ from each other regarding weed density, weed shoot fresh biomass, and green-ear and grain yields. Higher weed density and weed shoot fresh biomass values were found in subplots without weed control; lower values in subplots with weed control; and intermediate values in intercropped subplots, indicating that cowpea plants showed, to a certain extent, control over weeds. The subplots without weed control and the intercropped plots showed lower green-ear and grain yields. Although the cowpea varieties had a certain control over weeds, they also competed with the corn plants, reducing yield. The cowpea cultivars did not produce grain, certainly due to the strong corn and weed competition against cowpea plants. 


\section{LITERATURE CITED}

BARTLETT, M. S. Some examples of statistical methods of research in agriculture and applied biology. J. Roy Stat. Soc., v. 4, n. 1, p. $137-183,1937$

BARTLETT, M. S. The use of transformations. Biometrics, v. 3 , n. 1, p. $39-52,1947$.

BEGNA, S. H. et al. Morphology and yield response to weed pressure by corn hybrids differing in canopy architecture. Eur. J. Agron., v. 14, n. 4, p. 293-302, 2001

BUHLER, D. D. Weed population responses to weed control practices. I. Seed bank, weed populations, and crop yields. Weed Sci., v. 47, n. 4, p. 416-422, 1999

CARRUTHERS, K. et al. Intercropping corn with soybean, lupin and forages: weed control by intercrops combined with inter-row cultivation. Eur. J. Agron., v. 8, n. 3-4, p. 225-238, 1998.

CREAMER, N. G.; BALDWIN, K. R. An evaluation of summer cover crops for use in vegetable production systems in North Carolina. HortScience, v. 35, n. 4, p. 600-603, 2000 .

EHLERS, J. D.; HALL, A. E. Cowpea (Vigna unguiculata L. Walp.). Field Crops Res., v. 53, n. 1, p. 187-204, 1997.

EMPRESA BRASILEIRA DE PESQUISAAGROPECUÁRIA - EMBRAPA. Centro Nacional de Pesquisa do Solo. Sistema brasileiro de classificação de solos. Brasília: Serviço de Produção de Informação, 1999. 412 p.

FAO/UNESCO. Digital soil map of the world and derived soil properties. Rome: Information Division/FAO, 2006. CD-ROM

GOMES, J. K. O. et al. Effects of weed control through cowpea intercropping on maize morphology and yield. Planta Daninha, v. 25, n. 3, p. 433-441, 2007.

HOLLANDER, N. G.; BASTIAANS, L.; KROPFF, M. J. Clover as a cover crop for weed suppression in an intercropping design. I. Characteristics of several clover species. Eur. J. Agron., v. 26, n. 2, p. 92-103, 2007.

HUTCHINSON, C. M; McGIFFEN, M. E.Cowpea cover crop mulch for weed control in desert pepper production. HortScience, v. 35, n. 1, p. 196-198, 2000.

KUCHINDA, N. C. et al. On-farm evaluation of improved corn varieties intercropped with some legumes in the control of Striga in the Northern Guinea savanna of Nigeria. Crop. Protec., v. 22, n. 3, p. 533-538, 2003.
MOTA, J. C. A. Caracterização física, química e mineralógica, como suporte para o manejo, dos principais solos explorados com a cultura do melão na Chapada do Apodi - RN. 2004. 96 f. Dissertação (Mestrado em Solos e Nutrição de Plantas) - Universidade Federal do Ceará, Fortaleza, 2004.

NALEWAJA, J. D. Cultural practices for weed resistance management. Weed Technol., v. 13, n. 1, p. 643-646, 1999.

NGOUAJO, M.; LEMIEUX, C.; LEROUX, G. D. Prediction of corn (Zea mays) yield loss from early observations of the relative leaf area and the relative leaf cover of weeds. Weed Sci., v. 47, n. 2, p. 297-304, 1999.

OLASANTAN, F. O.; LUCAS, E. O.; EZUMAH, H. C. Effects of intercropping and fertilizer application on weed control and performance of cassava and corn. Field Crops Res., v. 39, n. 1, p. 63-69, 1994

RIBEIRO JÚNIOR, J. I. Análises estatísticas no SAEG Viçosa, MG: Universidade Federal de Viçosa, 2001. 301 p.

SHRESTHA, A. et al. Effect of tillage, cover crop and crop rotation on the composition of weed flora in a sandy soil.

Weed Res., v. 42, n. 1, p. 76-87, 2002.

SILVA, A. A.; VARGAS, L.; WERLANG, R. C. Manejo de plantas daninhas na cultura do milho. In: GALVÃO, J. C. C.; MIRANDA, G. V. Tecnologias de produção do milho. Viçosa, MG: Universidade Federal Viçosa, 2004a. p. 269-310.

SILVA, P. S. L.; SILVA, E. S.; MESQUITA, S. S. X.Weed control and green ear yield in corn. Planta Daninha, v. 22, n. 1 , p. $137-144,2004 b$

SKÓRA NETO, F. Controle de plantas daninhas através de coberturas verdes consorciadas com milho. Pesq. Agropec. Bras., v. 28, n. 10, p. 1165-1171, 1993.

SREENIVAS, G.; SATYANARAYANA, V. Nutrient removal by weeds and corn. Ind. J. Agron., v. 41, n. 1, p. 160-162, 1996.

STEINMAUS, S. et al. Mulched cover crops as an alternative to conventional weed management systems in vineyards. Weed Res., v. 48, n. 1, p. 273-281.

THOMAS, P. E. L.; ALLISON, J. C. S. Competition between corn and Rottboellia exaltata. J. Agric. Sci., v. 84, n. 1, p. 305-312, 1975.

WANG, G. et al. Competitiveness of erect, semierect, and prostate cowpea genotypes with sunflower (Helianthus annuus) and purslane (Portulaca oleracea). Weed Sci., v. 52, n. 3, p. 815-820, 2004. 